\title{
Ecossocialismo, romantismo e (auto)crítica da modernidade em Michael Löwy*
}

\section{Fabio Mascaro Querido**}

Resumo: Partindo da concreticidade da crise ecológica e das transformaçóes contemporâneas no âmbito dos processos de acumulação capitalista, o objetivo geral deste artigo é versar algumas notas preliminares a propósito da perspectiva teórica e política do assim chamado ecossocialismo, tal qual formulado em Michael Löwy. "Corrente de pensamento e de ação" cuja resposta à crise ecológica, a um só tempo romântica e socialista, constitui igualmente uma crítica às potencialidades destrutivas contidas no interior do paradigma societário e produtivo da modernidade. Neste trajeto, busca-se uma aproximação à apropriação löwiniana da obra de Walter Benjamin, especialmente de sua crítica do "progresso" moderno e das ideologias apologetas da "modernização". Almeja-se assim antever a forma através da qual Michael Löwy e os ecossocialistas respondem às profundas transformaçóes da (pós) modernidade capitalista contemporânea, com ênfase particular sobre um argumento central projetado na obra do intelectual franco-brasileiro, qual seja: a defesa da necessidade de que o marxismo radicalize "sua crítica da modernidade, do paradigma da civilização ocidental, industrial, moderna, burguesa” (LÖWY, 2000c, p.242), argumento que o levaria, já em meados da década de 1980, a valorizar as potencialidades revolucionárias subjacentes a crítica romântica da modernidade. Por fim, indaga-se sobre a projeçáo ecossocialista da necessidade de superação revolucionária do paradigma civilizatório propalado pelo capitalismo moderno. Palavras-chave: Michael Löwy; ecossocialismo; romantismo; marxismo; modernidade.

Eco-socialism, romanticism and the (self)critique of modernity by Michael Löwy

Abstract: Starting from the concreteness of the ecological crisis and contemporary transformations in the context of the processes of capitalist accumulation, the most general aim of this article is

* Recebido em 15 de agosto de 2008. Aprovado para publicação em 26 de maio de 2009.

" Fabio Mascaro Querido é mestrando em Sociologia pela Faculdade de Ciências e Letras, Unesp/Araraquara e bolsista $\mathrm{CNPq}$ 
to indicate some preliminary notes from the theoretical and political perspective of the so-called eco-socialism formulated by Michael Löwy. At the same time romantic and socialist, this "current of thought and action" is a response to the ecological crisis, and also a critique of the destructive potential contained in the social and productive paradigm of modernity. In this way, this article seeks an approach similar to Löwy's incorporation of the work of Walter Benjamin, especially in his critiques of the modern "progress" and the apologetic ideologies of "modernization". Thereby, it aims to understand how Michael Löwy and the eco-socialists respond to the profound transformations of contemporary capitalist (post) modernity, with a particular emphasis on a central argument raised from the work of the French-Brazilian intellectual, which is: the defense of the need for Marxism to radicalize "its criticism of modernity, of the paradigm of Western, industrial, modern, bourgeois civilization" (LÖWY, 2002, p.242), an argument that has led him, in the mid-1980s, to appreciate the "revolutionary" potential underlying the "romantic" critique of modernity. Finally, it inquires about the "eco-socialist" projection regarding the need to revolutionarily overcome the civilizing paradigm spread by modern capitalism.

Keywords: Michael Löwy; eco-socialism; romanticism; marxism; modernity.

\section{A CRISE ECOLÓGICA NO CORAÇÃO DA CRISE DA MODERNIDADE}

As potencialidades destrutivas do capitalismo, subjacentes à combinação aparentemente paradoxal entre uma racionalidade parcial envolta em todo um complexo de irracionalidade geral ${ }^{1}$, obtiveram um crescimento significativo a partir, sobretudo, das reconfiguraçóes geoeconômicas que se efetivaram após a derrocada dos chamados "anos dourados" do capital, no início da década de 1970; ao declínio das políticas macroeconômicas keynesianas, seguiu-se, como alternativa à crise de valorizaçáo do capital, um predomínio cada vez maior das políticas neoliberais, sob as quais o caráter destrutivo do capitalismo com relação aos ecossistemas só se fez aumentar, principalmente na América Latina.

A emergência da crise ecológica, nesse contexto, tornou visível a concretude mais ampla da "crise estrutural" (MÉSZÁROS, 2002, p.603) do processo de acumulaçáo capitalista, de onde se consubstanciou o colapso dos padróes propriamente modernos de seu desenvolvimento, inclusive em sua versáo pretensamente socialista. Bem entendido, a crescente "mundializaçáo" do capital confirmaria uma situação em que "as ameaças contra as condiçôes físicas de reprodução da vida atingem, em numerosos países e até em regiốes inteiras, uma dimensão muito mais trágica que no início do século XX" (CHESNAIS; SERFATI, 2003, p.68). Em outros termos, tratar-se-ia da "ativação dos limites absolutos do capital”, tal qual assevera István Mészáros (2002, p.216).

\footnotetext{
1 "Toda a estrutura da produção capitalista repousa sobre [a] interação entre uma necessidade submetida a leis estritas em todos os fenômenos isolados e uma irracionalidade relativa do processo como um todo" (LÚKACS, 2003, p.225).
} 
Mais do que isso, o período que se estende das derrotas políticas da esquerda em 1968 até a crise mais aguda do capital a partir de meados da década de 1970 (e cuja expressáo sintomática foi, sem dúvida, a crise do petróleo de 1973) impulsionou um grande número de teorias favoráveis a uma transformaçáo e, quando muito, a uma superaçáo dos paradigmas intelectuais e políticos ocidentais. Anunciava-se assim a gênese de uma nova fresta a ser preenchida pelo pensamento social, ampliando sobremaneira os discursos teóricos voltados para a afirmaçáo da necessidade de um novo estágio de compreensão das sociedades humanas. Abria-se o cenário para os imperativos de reavaliação das premissas básicas da modernidade. No limite, é como se a crise dos padrôes de acumulação capitalista tivesse propiciado uma nova inflexão no interior das correntes de pensamento, inflexáo esta marcada pela derrota da esquerda política "clássica" - vale dizer, propriamente moderna.

Em certa medida, o próprio surgimento dos movimentos ecológicos constitui parte importante desse processo, no âmbito do desenvolvimento dos assim chamados novos movimentos sociais. Para John Bellamy Foster (1999, p.161), é possível antever, na constituição mesma dos movimentos ecológicos, a existência de "certos pressupostos anti-modernistas (pós-modernistas ou pré-modernistas) que se tornaram sacrossantos dentro de boa parte da Teoria Verde". Identificando Marx e o marxismo como uma espécie de "versão extrema" de modernismo, "o verdadeiro ambientalismo, parece, demanda nada menos que a rejeição da própria modernidade". Opondo-se a tal rejeiçáo sumária da modernidade ${ }^{2}$, diz Foster: "Tornou-se moda em anos recentes [...] identificar o crescimento da consciência ecológica com a 'atual contestação pós-moderna da metanarrativa do Iluminismo"” (idem).

\section{MARXISMO E ECOLOGIA}

Seja como for, os movimentos ecológicos tradicionais constituíram-se, em larga medida, à revelia de qualquer análise crítica da economia política capitalista, em consequência de suas desconfianças para com o ímpeto produtivista que, segundo eles, marcara toda a obra de Marx. Com efeito, desde seus primórdios, divergências substanciais vêm mantendo, até os dias atuais, uma separação e, quando muito, uma troca de acusaçóes entre ecologistas e marxistas, ou, como se acostumou a dizer, entre "verdes" e "vermelhos". A ampla maioria dos movimentos ecológicos acusa Marx e Engels, e o marxismo em geral, de partilharem uma concepção histórica prometeica e/ou produtivista, uma vez que teriam aderido acriticamente ao progresso das forças produtivas, náo levando em conta,

2 'Seria um erro ver a solução do problema ecológico como a de rejeitar a 'modernidade' em nome de alguma abstrata e amorfa 'pós-modernidade', rejeitando, ao mesmo tempo, as correntes de pensamento que proporcionam uma crítica sistemática ao capitalismo. Em vez disso, temos que reconhecer que é necessário lutarmos com a modernidade - acima de tudo com a modernidade capitalista - e transformá-la” (FOSTER, 1999, p.173). 
suficientemente, os perigos e as forças destrutivas que esse avanço material táo celebrado poderia legar a humanidade, em particular à natureza ${ }^{3}$.

Desde pelo menos a década de 1970, momento do despertar da "consciência ecológica" (VIOLA, 1987, p.6), alguns autores marxistas vêm tentando costurar uma reflexão em torno dos pressupostos e dos novos desafios legados pela crise ecológica, almejando redefinir os termos da análise crítica do capitalismo em tempos contemporâneos. É bem verdade que, conforme alerta Michael Löwy,

hoje, ainda, o marxismo está longe de ter preenchido o atraso nessa área", e o "movimento operário tradicional na Europa - sindicatos, partidos sociais-democratas e comunistas - permanece ainda profundamente marcado pela ideologia do 'progresso' e pelo produtivismo (LÖWY, 2005, p.45).

Ainda assim, é possível avistar o desenvolvimento de alguns princípios de sensibilização ecológica no espectro da esquerda social e das correntes - de pensamento e de ação - autodenominadas socialistas.

Em geral, muitas foram (e certamente ainda seráo) as formas através das quais o marxismo se debateu com os percalços ecológicos do capitalismo. Para o "marxista-polanyista" norte-americano James O'Connor (1992), por exemplo, seria preciso acrescentar à primeira contradição do capitalismo (aquela entre as forças e as relaçóes de produção) uma segunda, cujos desdobramentos são absolutamente contemporâneos: trata-se da contradição entre as forças produtivas e as condiçōes de produção (trabalhadores, espaço urbano, a natureza). François Chesnais e Claude Serfati (2003, p.39), por seus turnos, são signatários da ideia de que, no espectro de palavras como ecologia e meio-ambiente, escondem-se "nada menos do que a perenidade das condiçóes de reprodução social de certas classes, de certos povos e, até mesmo, de certos países". Mais ainda, os autores defendem que, em ultima instância, "a crise ecológica planetária tem sua origem nos fundamentos e nos princípios de funcionamento do capitalismo", que "vê levantar-se contra si as consequências da relaçáo que instituiu, desde suas origens, com a natureza” (ibidem, p.41).

Tal processo, aprofundado pela nova liberdade do capital - plenamente conquistada entre os anos de 1992-1994-, revelaria, além do que, a necessidade de uma "crítica renovada do capitalismo", capaz de estabelecer um vínculo, "de forma indissociável”,

\footnotetext{
${ }^{3}$ Para o "ecologista social" John Clark, por exemplo, "o homem prometeico de Marx [...] é um ser que não se sente em casa na natureza, que não vê a Terra como a 'morada' da ecologia. É um espírito indomável que deve submeter a natureza em sua busca da auto-realização [...] Para tal ser, as forças da natureza, seja na forma de sua própria natureza interna ingovernável ou dos poderes ameaçadores da natureza exterior, devem ser subjugadas" (CLARK apud FOSTER, 1999, p.162).

4 "Entre 1992 e 1994, o capital terminou de destruir os entraves essenciais a sua liberdade de movimentaçáo e a sua capacidade de exploração dos proletários” (CHESNAIS, 2007, p.13).
} 
entre "a exploração dos dominados pelos possuidores de riqueza e a destruição da natureza e da biosfera" (ibidem, p.40). Assim, o marxismo deveria perceber que, de uma vez por todas,

[...] a análise da economia mundial como totalidade não pode mais ser realizada somente sob o ângulo das "relaçôes dos homens entre si", mas deve integrar, também, a dimensão das relações dos homens com a natureza. (CHESNAIS, 2007, p.15.)

Daí que, no limite,

hoje, ser fiel a Marx é relê-lo para procurar com ele (e não apenas em seu trabalho) todos os traços predatórios e parasitários, assim como todas as tendências à transformação das forças inicialmente ou potencialmente produtivas em forças destrutivas, que estavam inscritas nos fundamentos do capitalismo desde o início, mas cujo tempo de gestação e de maturação foi muito longo. (CHESNAIS; SERFATI, 2003, p.50.)

\section{O ECOSSOCIALISMO COMO RESPOSTA ANTICAPITALISTA À CRISE ECOLÓGICA}

É nesse sentido que se apresenta o ecossocialismo, movimento fundado a partir das necessidades de se articular as lutas das classes subalternas àquelas que se referem à defesa do meio-ambiente. Mas o que é, afinal, o ecossocialismo? Para Michael Löwy (2005, p.47), uma de suas figuras intelectuais mais destacadas, "trata-se de uma corrente de pensamento e de açáo ecológica que faz suas as aquisiçóes fundamentais do marxismo ao mesmo tempo que o livra das suas escórias produtivistas"-, englobando "as teorias e os movimentos que aspiram a subordinar o valor de troca ao valor de uso, organizando a produção em função das necessidades sociais e das exigências da proteção do meio-ambiente" (ibidem, p.49).

Os ecossocialistas, na contramão da proclamação de um "adeus à classe operária", como fez o ex-marxista convertido à ecologia André Gorz, compreendem que os trabalhadores, assim como as classes subalternas em sua totalidade, constituem uma força essencial para qualquer transformação radical do sistema que originou a crise ecológica a que estamos submetidos. Segundo anunciam em seu Primeiro manifesto, o

[...] ecossocialismo retém os objetivos emancipatórios do socialismo da "primeira época", ao mesmo tempo em que rejeita tanto os objetivos reformistas da socialdemocracia quanto as estruturas produtivistas das variaçôes burocráticas do socialismo. [Afinal, a] ausência de uma postura anticapitalista coerente levou a maior parte dos partidos verdes europeus - na França, Alemanha, Itália, Bélgica - a tornar-se simples partidários "ecorreformistas" da gestấo social-liberal do capitalismo pelos governos de centro-esquerda. (ibidem, p.46.) 
Em face do caráter reificado do capital, cuja lógica é estruturalmente incompatível com critérios éticos, Löwy sustenta a necessidade de construçáo de uma ética ecossocialista, fundada sob valores humanos qualitativos, na contramão da máquina de quantificação do capital. Para ele (ibidem, p.67), uma ética ecossocialista deveria colocar-se em franca oposição ao caráter impessoal e fundamentalmente não-ético, como já demonstrado por Weber, da economia capitalista 5 . No limite, tratar-se-ia de se buscar uma revalorização daqueles valores éticos já encontrados nas lutas camponesas e populares contra a mercantilizaçáo capitalista na Inglaterra do século XVIII, valores nomeados outrora como parte da "economia moral da multidão" pelo historiador "marxista-romântico" britânico E. P. Thompson. Diz Löwy que "o socialismo moderno é herdeiro desse protesto social, dessa 'economia moral"' (ibidem, p.70).

A "ética ecossocialista" a que se refere Löwy funda-se, sobretudo, em torno de uma ética social (assentada na necessidade da construçáo de um novo paradigma de produção e distribuição), de uma ética igualitária (baseada na apropriação coletiva dos meios de produção e na distribuição dos bens e serviços de acordo com as necessidades socialmente estabelecidas), de uma ética democrática (consubstanciada pela socialização democrática das forças produtivas), de uma ética responsável (para com a manutenção da espécie humana e da humanidade enquanto tal). Enfim, de uma ética radical, voltada para a luta radical por um novo modelo de civilizaçáo (ibidem, p.76) ${ }^{6}$.

A concretização dessa "utopia revolucionária de um socialismo verde" implicaria, além do mais, na articulação de uma pauta de reivindicaçóes mínimas que, levadas aos últimos termos, poderiam se tornar um ponto de convergência para o debate conjunto das questôes sociais e da problemática ecológica. "Algumas demandas imediatas já são, ou podem rapidamente se tornar, o ponto de convergência entre movimentos sociais e movimentos ecológicos, sindicatos e defensores do meio-ambiente, 'vermelhos' e verdes'” (ibidem, pp.60-61).

Dentre essas reivindicações mínimas, destacam-se a "promoção dos transportes públicos", "a luta contra o sistema de dívidas e os 'ajustes' ultraliberais impostos pelo FMI e pelo Banco Mundial aos países do Sul", a "defesa da saúde pública" e a "redução do tempo de trabalho como resposta ao desemprego e como visão da sociedade que privilegie o tempo livre em relação à acumulação de bens" (ibidem, p.61). Nesse sentido,

\footnotetext{
5 Em Weber, encontram-se as seguintes palavras - citadas por Löwy: "Em contraste com qualquer outra forma de dominação econômica do capital, devido ao seu 'caráter impessoal', não poderia ser eticamente regulamentada. [...] A competição, o mercado, o mercado de trabalho, o mercado monetário, numa palavra, consideraçóes 'objetivas', nem éticas, nem antiéticas, mas simplesmente náo-éticas [...] ordenam o comportamento no ponto decisivo e introduzem instâncias impessoais entre os seres humanos referidos" (WEBER apud LÖWY, 2005, p.68).

${ }^{6}$ Em recente entrevista à revista Fórum: outro mundo em debate (FARIAS; SOARES, pp.32-33), Löwy, após defender a necessidade de que um possível "socialismo do século XXI" seja capaz de incorporar as "experiências dos movimentos sociais", de "aprender com o movimento camponês, com o movimento das mulheres e com os movimentos das comunidades oprimidas", assinala a importância da incorporação da "questáo do meio-ambiente", afirmando que "o marxismo do futuro tem que ser um marxismo ecológico, um ecossocialismo. Senão vai estar fora da realidade do século XXI".
} 
a luta conjunta por reformas ecossociais pode impulsionar uma dinâmica de mudança, de transição entre os combates "mínimos", por assim dizer, e o programa máximo, "com a condiçấo de que" - defende Löwy -"se recusem os argumentos e as pressôes dos interesses dominantes, em nome das 'regras do mercado', da 'competitividade' ou da 'modernização'” (ibidem, p.60).

$\mathrm{Na}$ práxis social realmente existente, todavia, não são poucos os obstáculos enfrentados pelas tentativas de se estabelecer uma aliança entre os movimentos ecológicos e o socialismo. $\mathrm{Na}$ verdade, a concretização de tal aliança requer, antes de tudo, que os movimentos ecológicos compreendam a dimensão anticapitalista do seu combate e que, por sua vez, o marxismo saiba reconhecer a extensão ecológica da luta contra o capitalismo. "A convergência dos dois e a formação de um pensamento socialista ecológico é um dos grandes desafios para a renovaçáo do marxismo e do movimento revolucionário no século XXI" (LÖWY, 2000c, p.247).

De um lado, a ecologia, inclusive nos países do "Sul", poderia proporcionar ao pensamento socialista novos elementos para se pensar o tempo em acordo com o ritmo das necessidades sociais e naturais, desenvolvendo uma concepçáo de planejamento contraposta ao imediatismo da lógica mercantil (ROUSSET, 2000, p.5); de outro, o marxismo poderia contribuir para que os ecologistas reconheçam as determinaçóes propriamente sistêmicas e estruturais responsáveis pela crise ecológica, atentando para as potencialidades destrutivas (e, neste sentido, antinaturais) do paradigma capitalista (ou mesmo em sua versão pretensamente socialista) de produção e acumulação de capital.

A constituição de uma unidade de tamanha magnitude sugere, portanto, a necessidade de que o marxismo abandone de uma vez por todas alguns de seus supostos excessivamente amparados nas ideologias do progresso. Ao recriar a natureza e as necessidades humanas, moldando-as de acordo com as astúcias de seu paradigma produtivo, o capitalismo consolidou a formação de um homem econômico, cuja aparência eterna e natural foi assimilada não só pela economia política clássica, mas também em muitos momentos pelo próprio antagonista revolucionário do capitalismo, vale dizer, o marxismo (THOMPSON, 2005, p.23). Definitivamente, a conformação de uma aliança entre crítica social e crítica ecológica do capitalismo, tal qual propóem os ecossocialistas, exige que "essa ideia seja posta em dúvida" (idem).

O epicentro dessa concordância mínima reside na convicção de que a crise ecológica e a crise social possuem uma origem comum, qual seja, o próprio capitalismo. Afinal, a crítica social marxista e os movimentos ecológicos confrontam-se essencialmente contra um grande adversário em comum: o fetichismo mercantil, cujas prerrogativas temporais são absolutamente incompatíveis com os ritmos dos processos naturais e com o que há de natural no ser humano (BENSAÏD, 1999, p.435). Em palavras do Manifesto ecossocialista internacional:

Na nossa visão, as crises ecológicas e o colapso social estáo profundamente relacionados e deveriam ser vistos como manifestaçôes diferentes das mesmas forças estruturais. As 
primeiras derivam, de uma maneira geral, da industrialização massiva, que ultrapassou a capacidade da Terra absorver e conter a instabilidade ecológica. O segundo deriva da forma de imperialismo conhecida como globalizaçáo, com seus efeitos desintegradores sobre as sociedades que se colocam em seu caminho. Ainda, essas forças subjacentes são essencialmente diferentes aspectos do mesmo movimento, devendo ser identificadas como a dinâmica central que move o todo: a expansão do sistema capitalista mundial.(LÖWY; KOVEL, apud LÖWY, 2005, p.85.)

\section{SOCIALISMO, ROMANTISMO E ECOLOGIA: A AUTOCRÍTICA DA MODERNIDADE}

Em última análise, a aposta de Michael Löwy no movimento ecossocialista pode ser pensada como um momento fundamental da renovação do marxismo, destituindo-o de seus escólios produtivistas, fincados nas prerrogativas das ideologias apologetas do "progresso" e da modernização. Na verdade, a busca por uma junção entre socialismo e ecologia (ou questão social e questão ecológica) constitui parte de um projeto mais abrangente, qual seja: a elaboração de uma perspectiva anticapitalista capaz de seguir para além dos percalços destrutivos da modernidade, superando tanto sua lógica reificada quanto seu aparelho produtivo potencialmente destruidor. Tratar-se-ia, no limite, de uma transformação qualitativa dos paradigmas de desenvolvimento alimentados pela modernidade. $\mathrm{O}$ ecossocialismo, enquanto resposta anticapitalista à crise ecológica, seria táo somente a tentativa de restituir aqueles elementos de crítica à civilizaçáo moderna e industrial que se postam no interior do socialismo e da ecologia (ou, pelo menos, de algumas de suas correntes), e que prescrevem a ambos a condição de "herdeiros da crítica romântica", a despeito de suas eventuais divergências.

Para o intelectual franco-brasileiro (LÖWY, 1995, p.255), "o movimento ecológico constitui, neste final de século XX, a mais importante forma de renovação da crítica romântica contra a civilização industrial moderna”, e sua radicalidade é tanto maior quanto mais ele consegue por em questáo os desígnios da acumulaçáo capitalista/moderna, revelando, ainda que sem intenção explícita, os elementos mais expressivos de nossa verdadeira crise de civilização. Em Löwy, a valorização das potencialidades revolucionárias do que ele compreende como "visão social de mundo romântica" coincide com a necessidade de se pensar uma ruptura qualitativa com as formas de desenvolvimento propaladas pela modernidade burguesa, e seguidas à risca pelas versóes alternativas do leste europeu.

Em uma entrevista que nos concedeu em julho de 2008 (QUERIDO, 2009, p.180), o próprio Michael Löwy afiança que seu "interesse pelo romantismo decorre de seu potencial critico em relação à modernidade burguesa e da riqueza de suas imagens de um outro mundo possível". Na perspectiva por ele construída (muitas vezes em companhia de Robert Sayre), o romantismo não se reduz, como se costuma pensar, a uma escola literária do século XIX; para além disso, seu espectro ultrapassa o domínio das formas estéticas tradicionais, comportando, através de um eixo interno comum - ideia- 
-força - que lhe é singular, os vários elementos aparentemente contraditórios assumidos por suas manifestaçóes concretas. Para Löwy (LÖWY; SAYRE, 1995, p.36), a coerência interna da visão de mundo romântica não seria outra senão a oposição ao mundo burguês moderno. Em suas palavras,

[...] a característica essencial do anticapitalismo romântico é uma crítica radical à moderna civilização industrial (burguesa) - incluindo os processos de produção e de trabalho - em nome de certos valores sociais e culturais pré-capitalistas. [Todavia] a referência a um passado (real ou imaginário) não significa necessariamente que tenha uma orientação reacionária ou regressiva: pode ser revolucionária tanto quanto conservadora. (LÖWY, 1990, p.36; grifos do autor)

A conexão entre socialismo e ecologia, enquanto formas de autocrítica à modernidade burguesa, seriam impulsionadas, portanto, através do resgate do legado romântico do qual são signatários. Em Michael Löwy, a noção de modernidade, epicentro por excelência de sua definiçáo do romantismo (como sombra projetada coextensiva à civilização moderna), construir-se-ia a partir de uma "fusão", ou melhor, de uma incorporaçáo de alguns temas weberianos ao arcabouço metodológico marxista de análise das relaçôes sociais.

Como não poderia deixar de ser, tal empresa segue a risca a crítica ao capitalismo moderno já presente em História e consciência de classe, publicado por Lukács em 1922, e considerado pelo próprio Löwy como o fundador de uma corrente substancial do marxismo ocidental, a saber: o "marxismo weberiano" (LÖWY, 1995). Para o intelectual franco-brasileiro,

[...] fusionando a categoria weberiana de racionalidade formal - caracterizada pela abstração e quantificação - com as categorias marxianas de trabalho abstrato e de valor de troca, Lukács reformulou a temática do sociólogo alemão na linguagem teórica marxista. (idem.)

Pautando-se por uma leitura marcadamente hegeliana do marxismo, Lukács analisa com muita acuidade as consequências da reificação de todas as esferas componentes da totalidade da vida social, sob os imperativos da mercadoria e do valor de troca. Modernidade, assim sendo, expressa os desígnios do livre desenvolvimento do capitalismo moderno, no interior do qual se opera aquela "grande transformação" de que falara Karl Polanyi ${ }^{7}$, e cujo desdobramento socialmente necessário teria sido a formação, mais do que

${ }^{7}$ Em A grande transformação, obra publicada em 1944, o economista austro-húngaro Karl Polanyi sublinha o caráter substancialmente novo das mudanças iniciadas pela Revolução Industrial e intensificadas ao longo do século XIX, quando, pela primeira vez na história, a esfera econômica, sob a mediação do mercado auto-regulador, torna-se praticamente autônoma, impondo-se sobre o conjunto das demais instituiçóes sociais, e, por fim, subordinando a própria substância da sociedade às leis do mercado. 
de um modo de produção capitalista, de uma verdadeira civilização capitalista-moderna, em face da qual se define o próprio romantismo.

\section{WALTER BENJAMIN E A CRÍTICA DO “PROGRESSO" MODERNO}

Em Michael Löwy, a aproximação do marxismo com as lutas ecológicas vincula-se à exigência fundamental de "uma ruptura radical com a ideologia do progresso linear e com o paradigma tecnológico e econômico da civilização industrial moderna” (LÖWY, 2005, p.43). Tão somente assim, para ele, o marxismo poderá se reconstituir a altura dos desafios outorgados pela destrutividade do progresso capitalista nos tempos contemporâneos.

Conforme sugere o intelectual franco-brasileiro, a defesa da modernidade e do progresso, na atualidade, "serve, mais do que nunca, para legitimar um sistema de dominação do Norte sobre o Sul, da acumulação ilimitada de lucros em benefício de uma pequena elite e da destruição crescente do meio-ambiente" (LÖWY, 2000a, p.77). Não por acaso, a crítica do progresso catastrófico deve estar situada, hoje, no epicentro da crítica radical à lógica mercantil e ao "homem econômico", responsáveis pela crise ecológica que vivemos (THOMPSON, 2005, p.23). Nas palavras de Henri Lefebvre: "Esta época que se prolonga até os nossos dias e onde cada progresso é ao mesmo tempo um passo atrás relativo [...] tudo o que criou a civilização tem dupla face, dois gumes, contraditórios" (LEFEBVRE, 1969, p.270).

Walter Benjamin pode ser considerado como uma expressão do potencial das afinidades entre romantismo e socialismo ${ }^{8}$, revelando-se como um alicerce fundamental para a renovaçáo do marxismo nos tempos contemporâneos. Em Benjamin, encontrar-se-ia uma crítica radical das várias ideologias do progresso, inclusive daquelas ancoradas em alguns textos e passagens do próprio Marx. Na obra de Benjamin, "a revolução não é inevitável e ainda menos determinada pelo nível de desenvolvimento das forças produtivas: ao contrário, ele a concebe como uma interrupção de um progresso catastrófico" ${ }^{\prime}$ (LÖWY, 2000a, p.83). A crítica ao capitalismo é estendida, nesse ínterim, ao conjunto das prerrogativas do pensamento iluminista, em um movimento teórico que, levado a fundo, foi um dos mais tenazes questionamentos do positivismo e da racionalidade meramente parcial/instrumental da modernidade. Para Löwy, a formaçáo romântico-germânica de Benjamin, patente desde seus escritos de juventude, lhe forneceu um grande arsenal para a fundamentação de sua crítica ao progresso - e aí reside justamente, como bem salienta Löwy, uma das razóes do potencial crítico do filósofo alemáo ainda hoje.

\footnotetext{
${ }^{8}$ Mais ainda, Walter Benjamin constitui, nos termos de Löwy, um dos raros autores "nos quais a afinidade eletiva entre messianismo judaico e utopia libertária resultou numa verdadeira fusão, isto é, no nascimento de uma forma de pensamento nova, irredutível a seus componentes" (LÖWY, 1989, p.85).

9 "Ao contrário do marxismo evolucionista vulgar - que pode se referir evidentemente a alguns escritos dos próprios Marx e Engels - Benjamin não concebe a revolução como o resultado 'natural' ou 'inevitável' do progresso econômico e técnico, mas como a interrupção de uma evolução histórica que leva à catástrofe” (LÖWY, 2005, p.23).
} 
A dialética do progresso, diante da qual o marxismo oferece o método de análise mais adequado, deve ser compreendida à luz do desenvolvimento, no espectro do século XX, de uma "barbárie eminentemente moderna, da qual a Primeira Guerra dá um exemplo surpreendente, bem pior em sua desumanidade assassina que as práticas guerreiras dos conquistadores 'bárbaros' do fim do Império Romano” (LÖWY, 2000b, p.48). Dilui-se, assim, a oposição, consagrada pelo racionalismo Iluminista, entre civilização e barbárie, combinadas que estáo, na verdade, no interior dos mecanismos de dominaçáo social desenvolvidos no século XX.

Se nós nos referimos ao segundo sentido da palavra 'bárbaro' - atos cruéis, desumanos, a produção deliberada de sofrimento e a morte deliberada de não-combatentes (em particular, crianças) - nenhum século na história conheceu manifestaçóes de barbárie tão extensas, tão massivas e tão sistemáticas quanto o século XX. (Ibidem, p.47.)

\section{DESENVOLVIMENTO DAS FORÇAS PRODUTIVAS OU SUBVERSÃO DO APARELHO DE PRODUÇÃO?}

Evidentemente, a formulação de uma dialética do progresso requer, ao mesmo tempo, uma ponderação crítica em relação às próprias tecnologias desenvolvidas no bojo das forças produtivas capitalistas. Sabe-se que, em Marx, não há uma sistematização concreta em face da tecnologia. Mesmo porque, ao contrário dos economistas românticos, Marx náo se dispôs a criticar a maquinaria ou a tecnologia em si, mas sim a forma pela qual ela é utilizada no capitalismo. Diz o filósofo alemão, em $O$ capital:

Considerada em si mesma, a maquinaria reduz o tempo de trabalho, enquanto seu uso capitalista amplia a jornada do capital; em si mesma, ela torna o trabalho mais fácil, seu uso capitalista amplia sua intensidade; em si mesma, ela é uma vitória do ser humano sobre as forças da natureza, seu uso capitalista escraviza o homem à força da natureza; em si mesma, ela multiplica a riqueza do produtor, seu uso capitalista o pauperiza. (MARX apud LÖWY, 1990, p.205.)

Assim sendo, uma futura sociedade socialista poderia, em seus desígnios, fazer com que o progresso técnico possibilitasse "a redução geral do trabalho necessário à sociedade a um mínimo, o que corresponderá ao desenvolvimento artístico, científico etc dos indivíduos no tempo liberado, e com os meios criados, para todos" (idem). Note-se, portanto, que Marx muitas vezes pareceu conceber a estrutura industrial-tecnológica construída pelo capitalismo como um instrumento neutro, cuja essência coincidiria com seu "uso histórico". Se sob os imperativos da lógica capitalista a tecnologia esteve a serviço de uma produçáo potencialmente destrutiva, ela poderia muito bem, em uma sociedade emancipada, ligar-se às necessidades efetivamente humanas. 
Ainda assim, adverte Löwy (LÖWY, 1990, pp.205-206), se, por um lado, Marx náo afirmou explicitamente que a própria natureza do sistema tecnológico já estaria essencialmente afetada pelas suas origens capitalistas, não deixou dúvidas, por outro, do caráter contraditório e socialmente condicionado da maquinaria. Ora, para o intelectual franco-brasileiro, uma análise que apreenda o conjunto essencial do método marxiano poderá observar a inexistência em Marx de uma glorificação acrítica e unilateral - e, portanto, antidialética - do desenvolvimento das forças produtivas e do desenvolvimento tecnológico capitalista. Ao contrário, verificar-se-ia que, no âmago estrutural de sua obra, há uma veemente crítica ao fito altamente desumano (e desumanizador) da sociedade burguesa e de sua apologia ao desenvolvimento da técnica.

É bem verdade que muito dessa "qualidade dialética" (ibidem, p.206) das análises de Marx foram deixadas de lado por grande parcela dos círculos teóricos e políticos do marxismo ulterior. Essas apreciaçôes, radicalmente antiromânticas, seriam aquelas a predominar no marxismo já no final do século XIX e início do século XX. Na Rússia, em árdua luta contra os populistas (narodiniki), os marxistas, influenciados por Plekhanov, fizeram duros ataques aos críticos românticos, o que viria a desembocar em uma adesáo acentuadamente acrítica ao progresso técnico - visto como motor da história que estaria, por suas próprias condiçôes objetivas, em direção ao socialismo. Com exceção de Rosa Luxemburgo, cuja obra apresenta, segundo Löwy, uma significativa dimensäo romântica, essa tendência "modernista" daria o tom das concepçôes da II Internacional, como se pode ver, por exemplo, na obra de Kautsky.

Em contraposição a esse marxismo instrumental, para os ecossocialistas, o aparelho produtivo capitalista, "por sua natureza e estrutura", não é neutro, "mas está a serviço da acumulaçáo do capital e da expansáo ilimitada do mercado" (LÖWY, 2005, p.55). Nessa concepção, a transição socialista exigiria, antes de mais nada, uma transformação qualitativa dos próprios paradigmas de desenvolvimento, ou, no limite, uma "revolução energética", no interior da qual se consubstanciaria "a substituição das energias não-renováveis e responsáveis pela poluição e envenenamento do meio ambiente - carvão, petróleo e combustíveis nucleares - por energias 'leves' e renováveis: água, vento, sol” (idem). Em suas palavras, o marxismo do século XXI deveria, "contra uma certa vulgata marxista, que concebe a mudança unicamente com supressão de relaçóes sociais capitalistas" (compreendidas como obstáculos ao livre desenvolvimento das forças produtivas), "questionar a própria estrutura do processo de produção" (ibidem, p.76).

\section{A PRÁXIS E A SUPERAÇÃO REVOLUCIONÁRIA DA CIVILIZAÇÃO CAPITALISTA}

A bem dizer, o esforço teórico de Michael Löwy, semelhante em destacados aspectos àquele de seu amigo e companheiro de militância Daniel Bensaïd, parece se voltar irresolutamente para o resgate da dimensão crítica do marxismo em relação à razão moderna. 
$\mathrm{O}$ autor franco-brasileiro parece resgatar na obra marxiana aqueles elementos em que se ratifica com mais facilidade o quanto, no próprio Marx, já haveria, por dentro da tradição moderna e iluminista, uma superaçâo do caráter normativo e totalitário da razão positivista moderna. Uma superaçáo, diga-se de passagem, que náo abre máo, todavia, das potencialidades emancipatórias do legado iluminista ${ }^{10}$. Tal empreitada parece ter sido constituída como uma tentativa de redefinir os termos do projeto socialista à luz dos novos desafios postos pelo capitalismo contemporâneo - tal qual a crise ecológica -, como uma alternativa à crise da modernidade (que é também e, sobretudo, a crise do próprio capital) substancialmente diferente daquelas propaladas pelas novas teorias pós-modernas ${ }^{11}$.

Tratar-se-ia, no limite, não de se "conservar piedosamente um capital doutrinário", mas, antes, de se "enriquecer e transformar uma visáo de mundo à prova de práticas renovadas” (BENSAÏD, 2008, p.22). Nas palavras de Michael Löwy,

O marxismo não tem sentido se ele náo é crítico, tanto em face à realidade social estabelecida - qualidade que faz imensa falta aos "marxismos" oficiais, doutrinas de legitimação apologética de uma ordem "realmente existente" - quanto face a ele próprio, face a suas próprias análises, constantemente questionadas e reformuladas em função de objetivos emancipadores que constituem sua aposta fundamental. (LÖWY, 2000d, p.59; grifos do autor.)

Ao marxismo, portanto, restaria, à luz de sua aposta fundamental, recompor o seu sentido revolucionário, tarefa que requer tanto a superação de seus escólios deterministas de toda ordem quanto à incorporaçáo das práticas renovadas dos novos movimentos contra-hegemônicos. Deste modo, "o marxismo precisa, para enfrentar os problemas atuais, radicalizar sua crítica da modernidade, do paradigma da civilizaçáo ocidental, industrial, moderna, burguesa" (LÖWY, 2000c, p.242), encampando a defesa, diante da crescente "recusa dogmática da totalidade" (BENSAÏD, 2008, p.86), de uma "totalização aberta", tal qual diria Henri Lefébvre. Este seria o passo primeiro para a superaçáo dos dilaceramentos provocados pelo desenvolvimento da modernidade capitalista, cujo corolário básico teria sido não a unidade entre homem e natureza, tấo prometida em seu discurso filosófico originário, mas sim a ruptura trágica desta unidade, assentada na ideia

\footnotetext{
${ }^{10} \mathrm{Na}$ entrevista que nos concedeu (QUERIDO, 2009, p.183), Löwy afirma: "A modernidade tem de ser vista dialeticamente; [...] por um lado, temos as conquistas da Filosofia das Luzes e da Revolução francesa, os valores modernos de liberdade, igualdade e fraternidade. Por outro lado, o 'progresso' da civilização industrial capitalista moderna, que produziu Auschwitz e Hiroshima, e que está nos levando, com uma rapidez crescente, a um desastre ecológico de proporçōes inéditas".

${ }^{11}$ Afinal, tal como assevera Daniel Bensaïd (2008, p.13), não é possível "escapar, por simples decreto, dos efeitos concretos da subalternidade", tampouco, "por uma mudança de vocabulário, do léxico dos dominantes, se a realidade das relaçóes de força não for alterada".
} 
prometéica de que o domínio do primeiro sobre a segunda seria o fator preponderante do progresso (LEFÉBVRE, 1969, p.175).

Nos Manuscritos econômico-filosóficos, redigidos em 1844, Marx apresentava sua concepção do ser humano como ser, em primeira e última análise, natural, isto é, como "parte” da natureza. Para ele: "Dizer que a vida psíquica e intelectual do homem está indissoluvelmente ligada à natureza não significa outra coisa senão que a natureza está indissoluvelmente ligada com ela mesma, pois o homem é uma parte da natureza”. (MARX apud LÖWY, 2005, p.21). E, nessa perspectiva, a própria noção de comunismo inscrita nas formulaçóes marxianas seria nada menos do que a "verdadeira solução para o antagonismo entre o homem e natureza", que se expressa nas sociedades capitalistas através, dentre outros exemplos, das verdadeiras cisóes entre a cidade e o campo. Nas palavras de Alan Bihr:

[...] a utopia comunista deve romper com a concepçáo antropocêntrica da existência humana, baseando seu sentido não na separação entre o homem e a natureza, mas no pertencimento do homem à natureza, da qual é guardião e testemunha. Só assim o comunismo poderá significar a reconciliação do homem com a natureza, a naturalização do homem ao mesmo tempo que a humanização da natureza, para retomar as célebres fórmulas do jovem Marx (BIHR, 1999, p.141.)

A práxis revolucionária e a luta ecossocialista contra a civilização capitalista-moderna apresentam-se, portanto, como o momento de reunificaçáo das cisóes e das múltiplas dualidades que definem o mundo moderno (LEFÉBVRE, 1969, p.158). No limite, a práxis social e histórica constitui o momento privilegiado da reunificaçáo entre privado e público, particular e geral, e, mais importante aqui, entre natureza e homem. Para Henri Lefébvre, é na práxis que a dialética entre ser e consciência (ou entre realidade e apreensão subjetiva da realidade) se faz representar em sua unidade real, diluindo qualquer dicotomia possível entre mundo interior e mundo exterior/natural ou, melhor dizendo, entre sujeito e objeto (idem). A práxis configura-se, em última instância, como o momento profícuo à unificação dialética dos percalços da civilização moderna. Na formulação de Fredric Jameson (1992, p.291), a antecipação necessária de um futuro possível e necessário, voltado para a formulaçáo de um paradigma civilizatório radicalmente diferente daquele em que vivemos.

De uma perspectiva ecossocialista, este é o grande desafio dos tempos contemporâneos, onde a práxis revolucionária deve voltar a emergir como o horizonte possível da superaçáo da modernidade capitalista. E o marxismo, nesse sentido e medida, se insere como um momento indispensável de um ponto de vista ecológico radical, dentro do qual as raízes da crise ecológica devem ser buscadas não em determinaçóes extrínsecas às relaçóes sociais dominantes, mas sim nas próprias formas de produção e reprodução ampliada do capital, ou seja, nas características fundamentais da civilização capitalista. Superá-la, portanto, mais do que uma opção dentre outras, consiste no suposto básico de qualquer perspectiva social e ecológica verdadeiramente sustentável. 


\section{REFERÊNCIAS BIBLIOGRÁFICAS}

BENSAÏD, D. Marx intempestivo. São Paulo: Civilização Brasileira. 1999.

. Os irredutiveis: teoremas da resistência para o tempo presente. São Paulo: Boitempo, 2008.

BIHR, A. Da grande noite à alternativa: o movimento operário europeu em crise. Sáo Paulo: Boitempo, 1999.

CHESNAIS, F. "As contradições e os antagonismos próprios ao capitalismo mundializado e suas ameaças para a humanidade”. Revista Outubro, São Paulo, n. 16, 2007, pp.13-33.

CHESNAIS, F; SERFATI, C. "Ecologia e condições físicas de reprodução social: alguns fios condutores marxistas”. Crítica Marxista, São Paulo, n. 16, 2003, pp.39-75.

FARIA, G; SOARES, N. "À procura de um novo socialismo". Fórum: outro mundo em debate. São Paulo, n. 48, 2007, pp.32-33.

FOSTER, B.J. Marx e o meio ambiente. In: FOSTER, J. B. \& WOOD, E. M. Em defesa da história: marxismo e pós-modernismo. Rio de Janeiro: Jorge Zahar, 1999. JAMESON, F. O inconsciente político. São Paulo: Ática, 1992.

LEFÉBVRE, H. Introdução à modernidade. Rio de Janeiro: Paz e Terra, 1969.

LÖWY, M. "A dialética marxista do progresso". In: BENSAÏD, D.; LÖWY, M. Marxismo, modernidade e utopia. São Paulo: Xamá, 2000a, pp.77-83.

"Barbárie e modernidade no século XX". In: BENSAÏD, D.; LÖWY, M. Marxismo, modernidade e utopia. São Paulo: Xamã, 2000b, pp.46-57.

"De Marx ao ecossocialismo". In: SADER; GENTILI (orgs.). Pós-neoliberalismo II. Rio de Janeiro, Vozes, 1999. Ecologia e socialismo. São Paulo: Cortez, 2005.

"Figuras do marxismo weberiano" Disponível em: <http://anti-valor2.vilabol. uol.com.br/textos/outros/lowy_01.html>. Traduzido por Edmundo Lima de Arruda do original: "Figures du marxisme wébérien". Revue Actuel Marx, n. II. Paris, Presses Universitaires de France, 1995. Acesso em: 25/05/2008.

. "Marxismo: resistência e utopia". In: BENSAÏD, D.; LÖWY, M. Marxismo, modernidade e utopia. São Paulo: Xamã, 2000c, pp.241-247.

"Por um marxismo crítico". In: BENSAIID, D.; LÖWY, M. Marxismo, modernidade e utopia. São Paulo: Xamã, 2000d, pp.58-67.

Redenção e utopia: o judaísmo libertário na Europa central. Sáo Paulo: Companhia das Letras, 1989.

Romantismo e messianismo. São Paulo: Perspectiva: Edusp, 1990.

LÖWY, M.; SAYRE, R. Revolta e melancolia: O romantismo na contramão da modernidade. Rio de Janeiro: Vozes, 1995.

LUKÁCS, G. História e consciência de classe. São Paulo: Martins Fontes, 2003.

MÉSZÁROS, I. Para além do capital. Campinas/São Paulo: Unicamp/Boitempo, 2002. 
O'CONNOR, J. "La seconde contradiction du capitalisme: cause et conséquences”. Revue Actuel Marx: L'écologie, ce matérialisme historique. Paris, Presses Universitaires de France, 1992, n. 12 pp.30-36.

QUERIDO, F. M. "Utopias indisciplinadas de um marxismo para o século XXI: o marxismo como crítica da modernidade. Entrevista com Michael Löwy". Revista Lutas Sociais, n. 21/22, 2009, pp.179-185.

ROUSSET, P. "O ecológico e o social: combates, problemas, marxismos". Cadernos em Tempo, n. 3113, fevereiro de 2000. Disponível em: <www.ecossocialistas.org. br.>Acesso em: 23/07/2007.

THOMPSON, E. P. Costumes em comum: estudos sobre a cultura popular tradicional. São Paulo: Companhia das Letras. 2005.

VIOLA, E, J. "O movimento ecológico no Brasil (1974-1986): do ambientalismo à ecopolítica”. Revista Brasileira de Ciências Sociais, São Paulo, vol.1, n. 3, 1987, pp.5-26. 